\title{
The Impact of Working Capital Management on Firm Profitability: Evidence from Selected Wholesale Trade Firms in Addis Ababa, Ethiopia
}

\author{
Zewdu Negalign Kebede \\ Department of Accounting and Finance, University of Gondar
}

\begin{abstract}
Working capital management has a vital role for the success or failure of a firm because of its paramount impact on profitability and liquidity. The purpose of this study is to examine the impact of working capital management on profitability of large tax payer wholesale firms found in Addis Ababa city. The study used audited financial statement of 62 purposively selected wholesale firms for a period of 5 years from 2015 to 2019 . Data had been analysed by descriptive statistics and a multiple regression. The finding shows that CATAR and IHP had a significant positive relation with profitability meaning that firms maintains optimal level of inventory and higher level of current asset leads towards profitability respectively. Furthermore, negative and significant relationship between APP and CCC with profitability implies that a firm paying its obligation with earlier time and the shorter a time gap between cash outflows and inflows leads to higher profitability respectively. However, ARP and CLTAR had insignificant positive and negative relation with profitability respectively. To summarize, the study conclude that working capital management significantly affect profitability of wholesale firm.
\end{abstract}

Keywords: Working capital management, working capital policy, Profitability, wholesalers, and panel data

DOI: $10.7176 / \mathrm{DCS} / 11-8-01$

Publication date:October $31^{\text {st }} 2021$

\section{Introduction}

Working capital management is one of the core areas in which financial managers devote most effort in decision making in the field of corporate finance (Ross et al., 2008). Working capital management is very important part of corporate finance because of its paramount effect on profitability as well as liquidity of a company (Arshad and Gondal, 2013). Working capital management has undeniable role for success of firm since the primary objective of any firm is to maximize profit and increase shareholders wealth (Raheman and Nasr, 2007). Effective working capital management leads to towards better profitability, increase cash flows, decrease the needs of external financing and reduce failures of business (Charitou et al., 2010). In general, working capital management is very necessary for long lasting success of any business. However, making decision on working capital is more challenging due to its cyclical in nature and sensitive to change for various factors.

Working capital management involves the decision related to the amount and composition of current assets and current liability on the way profitability will be improved without affecting the liquidity position of a firm (Ross et al., 2008). Working capital means the amount of investment in short lived asset that changed in to cash within operating cycle. It includes cash and marketable securities, trade receivables, inventories, trade payables (Pandey, 2000). Working capital is the crucial area of financial management and plays a vital role in any industry. There is no actual standard on the amount of working capital needs for the day to day operations of the firm. The amount varies from industry to industry based on the nature of operation. Wholesale and retail firm's needs high amount of money invested in working capital, but requires less amount of investment in fixed asset compered to manufacturing and service sector (Nair, 2011).

There were mixed result on the relationship between working capital management and firm profitability of prior studies. Deloof (2003), Lazaridis \&Tryfonidis (2006), Ahmed et al., (2016) found a strong negative relationship between working capital management and firm profitability. On the contrary, Ali \& Ali (2012) and Hassan \& Ibrahim (2016) had found a strong positive relationship between working capital management with firm profitability. Others like Niresh (2012), Yadav \& Kumar (2014), Bjorkman \& Hillergren (2014), Amitdas (2015) found no significant relationship between working capital management and profitability.

Working capital management highly affects profitability of merchandise firms as confirmed by (Louw, 2014; Hassan \&Ali, 2016; Leeshan et al., 2016). In case of Ethiopia no empirical studies on the impact of working capital management on wholesale industry profitability. Besides, many merchandise business in Ethiopia do not properly manage their working capital (Deresse \&Abiy, 2014).

In general, due to contradiction of prior studies, the existence of working capital management problem on wholesale industry inspired the researcher to undertake this study. 


\section{LITERATURE REVIEW}

\subsection{Theoretical Frame Work; Definition and Concept}

The term working capital refers as the names it implies the firm investment in short term asset in order to carry out its day today business activities (Ross et al., 2008). Working capital represents the difference between current asset and liability (Kaveri, 1985). Working capital is the heart of every business concern. It is difficult for any business to continue its operation without adequate level of working capital. A decision made in one component of working capital has also effect in the other components of working capital and profitability. Poor working management is one of the causes for the failure of many businesses in developed as well as developing countries (Egbide, 2009). For smooth running an enterprise, adequate amount of working capital is very essential. The first primary need of working capital is to providing adequate investment in current asset that helps the firm to meet day to day working capital requirements as to cover its daily expenditures such as payroll, vendor invoices, and inventory purchases. Working capital needed for the firm in order to meet seasonal and some unexpected cash needs such as extensive marketing campaigns or carrying of special job. Working capitals also needed to sustain sales growth and to efficiently utilize fixed assets. If a firm is on the way of growth it needs addition investment on receivable, inventory and payable (Nair, 2011).

Working capital management means making decision related to how match a firm should invest on current asset for optimal decision making, on which components of working capital a firm should invest and how a firm raise funds in order to finance current assets. In other words, working capital management deals with the relationship between a firm short term assets and short term liabilities. The goal of working capital management is to ensure that the firm is able to continue its operations by achieving its solvency for immediate unexpected cash needs and for its long ran success Mawhiraju, 1999).

Working capital policy can be defined as guide line or strategy used by a firm to make decision related to the amount of investment in current asset and the way used by a firm to finance its current asset (Watson \& Head, 2007). There are three alternative working capital policy exists to wards investment and financing decision (Watson \& Head (2007). Those are;

Aggressive working capital policy: it is rigid approaches of working capital management. The more a firm follows aggressive policy, the higher its return however; its risk of solvency will be higher (Watson \& Head, 2007). Conservative working capital policy: it is flexible approaches of working capital and employs relatively large amount of cash, holding large amount inventory and follow liberal credit policy to increase sales, and used long term debt to finance its investment on current asset (Brigham \& Houston, 2003). The more firms adapts conservative working capital policy, the lower the risk of firm and profitability of firm (Paramasivan \& Subramanian, 2009).

Moderate working capital policy: it lies between aggressive and conservative working capital policy by avoiding two extremes. It is a type of policy try to meet optimal investment on level of current asset by avoiding excess and inadequate level (Brigham \& Houston, 2003).

Every decision on working capital management will affect either profitability or liquidity. Financial manager of every firms face the dilemma between profitability and liquidity when making decision in any area of corporate finance (Eljelly, 2004). Profitability means the ability of firms to raise anticipated return and maximize shareholders wealth whereas liquidity shows the ability of business to meet day to day obligation and unexpected cash needs. Profitability and liquidity are the two primary objective of any financial manager but they contradictory each other. When profitability increase liquidity decrease and vice versa (Padachi, 2006).

\subsection{Empirical Studies}

Raheman and Nasr (2007) studied the relationship between different variables of working capital management such as average collection period, inventory turnover in days, average payment period, cash conversion cycle and current ratio on the net operating profitability of Pakistan firms. The result indicated that there were significant negative relationship between measures of working capital management and profitability.

Mathuva (2010) investigate the impact of working capital management components on profitability on sample of 30 firms listed on Nairobi stock exchange for period of 6 years between1993 -1998. He found that there was highly significant negative relationship between receivable collection period and profitability; there was highly significant positive relationship between inventory conversion period and profitability; there was highly significant positive relationship between average payment period and profitability

Niresh (2012) examined the relationship between working capital management and financial performance of listed manufacturing firms in Sri Lanka. He found that there was no significant relationship between cash conversion cycle and profitability and insignificant positive relationship between current assets to total assets and profitability measures.

Mwangi et al. (2014) had studied the impact of working capital management on performance of NonFinancial Companies in Kenya for the period 2006 to 2012 on selected 42 non-financial companies listed in the Nairobi Securities Exchange. The result showed that aggressive financing policy had a significant positive impact 
on firm's performance and also conservative investing policy had significant positive effect on firm's performance.

Louw (2014) examined the relation between working capital management on profitability of South Africa retail firms. The result showed that reducing cash conversion cycle, average age of receivable, average age of inventory can help a firm to gain more profits. Amit Das (2015) examined the association between working capital management and profitability of pharmaceutical companies in India for a period of 2003 to 2013. The result showed that no significance relation exists between working capital management and profitability.

Ahmed et al. (2016) examined the link between working capital management and profitability in case of Pharmaceutical Sector in Pakistan for a period of 2005-2012. The result of this study showed that significant negative relationship between working capital and profitability. He concludes that efficient management of working capital enhances profitability of firm.

Leeshan et al. (2016) investigate does working capital management influence the performance of wholesale and property industry in Malaysia The result of the study indicate that CATAR and size had significant positive impact on the firm's Profitability.

Mbawni et al. (2016) examined the effect of working capital management on profitability of petroleum retail firms in Ghana over a six year period (2008-2013). The result of this study indicate that average days payable was the only variable had negative significant impact on profitability, others cash conversion cycle and average days receivable have positive relation with profitability but insignificant, and average days inventory had negative relation with profitability but insignificant.

Hassan and Ali (2016) had studied on the effects of working capital management on firm profitability in the merchandise firms in Mogadishu, Somalia. The study found that working capital management components were found significantly and positively influence firm profitability of merchandise.

In general what we understand from theoretical and empirical part of the study working capital management is essential for success of any organization particularly for wholesale and retail firms (Louw (2014). Inefficient management of working capital is one of the causes for the failure of many organizations in the past (Smith, 1973; Egbide, 2009). There were many studies exist on the relation between working capital management and profitability however, the results of the study mixed and contradict one with the other.

\section{III.METHODOLOGY}

\subsection{Research Design}

This study employed explanatory research design in order to examine the impact of working capital management on firms profitability. The choice of design is to establish the causal-effect relation between working capital management variables and profitability and to determine how profitability affected by working capital management.

\subsection{Source of Data and Sample of the Study}

The secondary data had been taken from large tax payer wholesale firms. The reason for selecting large tax payer wholesale trade firms was due to the availability of necessary data for the study. Firms which have annual sales greater than 27 million birr are included in large tax payer category. The new revision entry in to large tax category had been effective starting from August 7, 2013. The total number of population include in this study was (250) wholesale trade firm which submit their annual report to Ethiopian revenue and customs authority (ERCA) large tax payers office Addis Ababa up to August 312019 (ERCA,2019). Purposive sampling method was used in the study in order to included firms which have a complete record of financial statements for 5 years. Hence, the study selected 62 large tax payers wholesale trade firms found in Addis Ababa city for the period 2015 to 2019.

\subsection{Variable Description and Hypothesis}

Dependant Variable; This study used return on asset as proxy of dependant variable to measure profitability. It measures how a firm efficiently utilizing its operating asset to generate the given level of profit and it relates asset of firm with performance of firm (Padachi, 2006).

Explanatory variables;

Accounts Receivable Period (ARP): measure and used as proxy to credit policy and to measure its effectiveness. It can be calculated; $\quad \mathrm{ARP}=\frac{\text { Account recivable }}{\text { Sales }} * 365$ days.

Inventory Holding Period (IHP): It measures the effectiveness of firm in managing its inventory and to evaluate inventory policy. It can be calculated; IHP $=\frac{\text { Inventoy }}{\text { Cost of goods sold }} * 365$ days

Accounts Payable Period (APP): it used as proxy for account payable. This ratio calculated as $\mathrm{APP}=\frac{\text { Account Payable }}{\text { Cost of Goods Sold }} * 365$ days

Cash Conversion Cycle (CCC): measures the length of time a firm takes between cash out flows due to raw material purchase and cash inflows due to sale of final produced goods. It used a proxy to measure over all working capital management efficiency. It can be calculated as follows. CCC $=$ ARP + IHP- APP 
Current Asset to Total Asset Ratio (CATAR): it used to measure the working capital investment policy of a firm. This ratio calculated as CATAR $=\frac{\text { Current asset }}{\text { Total asset }}$

Current Liabilities to Total Assets Ratio (CLTAR): used to measure working capital financing policy of a firm in this study. This ratio calculated as follows.

\section{Control variables;}

$$
\text { CLTAR }=\frac{\text { Current laiablity }}{\text { Total asset }}
$$

Current ratio (CR), Firm size (FS) a proxy for size measured by natural logarithm of sales-Ln(Sales), Sales Growth (SG) and Debt ratio (DR) used as a control variables.

In order to examine the relationship between working capital management and wholesale profitability, the following hypotheses were developed:

H1: - There is a significant negative relationship between ARP and firm's profitability.

H2:-There is a significant negative relationship between IHP and firm's profitability.

H3:- There is a significant positive relationship between APP and firm's profitability.

H4:- There is a significant negative relationship between CCC and firm's profitability.

H5:- There is a strong negative relationship between CATAR and profitability of firms.

H6:-There is a significant positive relationship between CLTAR and profitability firms.

\subsection{Models for Data of Analysis}

In order to investigate the effect of working capital management on profitability the study developed a model previously used by (Raheman \& Nasr, 2007) which shown below;

ROA it $=\beta_{0}+\beta_{1}($ ARP it $)+\beta_{2}$ (IHP it) $+\beta_{3}($ APP it $)+\beta_{4}(C C C$ it $)+\beta_{5}($ CATAR it $)+\beta_{6}($ CLTAR it $)$ $+\beta_{7}(C R$ it $)+\beta_{8}(D R$ it $)+\beta_{9}($ SG it $)+\beta_{10}(F S$ it $)+\varepsilon$ it

Where:

$\beta_{0}=$ intercept of the regression, $\beta_{1}, \beta_{2} \ldots \ldots, \beta_{10}=$ coefficients of each respective explanatory variables, it=firm $\&$ time for each variable, and $\mathcal{E}=$ is the error term of the regression

\subsection{Data Analysis Method}

The data collected were analysed by using descriptive statistics and regression analysis. Descriptive analysis was used to provide detailed information about each variable. Multiple regression analysis particularly panel least square method analysis was used to determine the cause and effect relationship between working capital management and profitability. The overall analysis was takes place by using STAT software version 14.

\section{IV.RESULT AND DISCUSSION}

\subsection{Descriptive Statistics}

Table 1 shows descriptive statistics (mean, standard deviation, minimum and maximum) value of each variable for sample of 62 wholesale trade firms for the period of 5 years.

Table1: Descriptive Statistics

\begin{tabular}{|c|c|c|c|c|c|}
\hline Variable & Observation & Mean & Std.Dev. & Min & Max \\
\hline ROA & 310 & .1819308 & .1483115 & -.4467342 & .9464331 \\
\hline ARP & 310 & 42.2173 & 54.06657 & 0 & 800.3201 \\
\hline IHP & 310 & 130.4392 & 113.7179 & 0 & 683.1824 \\
\hline APP & 310 & 33.47166 & 52.90512 & 0 & 515.8735 \\
\hline CCC & 310 & 139.8146 & $128.5937-$ & -389.3947 & 1004.931 \\
\hline CATAR & 310 & .680861 & .2145146 & .0260178 & .8997179 \\
\hline CLTAR & 310 & .3418552 & .2164744 & .01234 & .660368 \\
\hline CR & 310 & 3.689126 & 5.811002 & .2773946 & 59.15891 \\
\hline DR & 310 & .5334693 & .2631619 & .0628168 & 1.693048 \\
\hline FS & 310 & 18.81718 & 1.120615 & 16.02424 & 23.48331 \\
\hline SG & 310 & .2810352 & .7260383 & -.8318409 & 7.280148 \\
\hline
\end{tabular}

Source: STATA out put of Data

As presents in the above table 1, the mean of profitability measured by ROA was on average $18.19 \%$. It means that, Ethiopian large wholesaler generate on average $18.19 \%$ from their total asset employed. The standard deviation of return on asset (ROA) is $14.83 \%$ with its minimum and the maximum value of $-44.67 \%$ and $95 \%$ respectively. The mean of ARP was 42.21 days. ARP can vary both sides by 54 days from the mean and its value ranges between zero and 800.32 days of minimum and maximum values respectively. The mean of IHP was 130 days. The standard deviation of IHP was 114 days and ranges between zero and 683 days of minimum and maximum values respectively. The mean of APP was 33 days. The standard deviation of APP was 53 days with 0 
and 516 days as minimum and maximum periods respectively. The mean of CCC was 140 days with the standard deviation of 129 days. The minimum value of CCC was -389 days with a maximum value of 1005 days. CATAR had an average of $68 \%$ of total asset and its standard deviation was $21.45 \%$. The minimum value was $2.6 \%$ with the maximum value of $89.97 \%$. CLTAR had an average of $34 \%$ with the standard deviation of $21 \%$. The maximum value was $66 \%$ with a minimum level of $9 \%$. CR had an average 3.65 times with standard deviation of 5.8. Average DR was $53.94 \%$ with a standard deviation of $26.31 \%$. SG was $28 \%$ on average with a standard deviation of $72 \%$. Lastly, FS was 18.69 on average with a standard deviation of 1.12 .

\subsection{Diagnostic test}

This section presents the results of major diagnostic tests that should be done before going to regression analysis.

\subsubsection{Normality test}

A normal distribution is not skewed and is defined to have a coefficient of kurtosis of 3 . A distribution said to be normal when it is symmetric about its mean. Brooks (2008) explained that residuals are normally distributed when the p-value given at the bottom of the normality test screen should be bigger than 0.05 . This assumption is particularly essential for small sample size specifically which is less than 100 observations. For sample size that is sufficiently large, the assumption of normality is relaxed (Gujarati, 2004).

\subsubsection{Autocorrelation test}

This study used Wooldridge test in order to check the presence of autocorrelations problem. The null hypothesis of the Wooldridge test was no autocorrelation in the model.

Table 2: Wooldridge test for autocorrelation

\begin{tabular}{|cl|}
\hline $\mathrm{F}(1,61)=$ & 0.771 \\
$\mathrm{Prob}>\mathrm{F}=$ & 0.3833 \\
\hline
\end{tabular}

(H0: no first-order autocorrelation)

As indicated in table 2, the result of autocorrelations test shows f- statistic of 0.771 with p value of 0.3833 hence the null hypothesis of no autocorrelation is failed to reject at $5 \%$.

4.2.3. Multicollinearity test

Multicollinearity occurs when explanatory variables are very highly correlated with each other (Brooks, 2008). Accoring to Hair et al. (2006) and Pallant (2005) explanations, multicollinearity is a serious problem when the correlation between two independent variables is more than or equal to $90 \%$. This study used correlation matrix to test multicollinearity.

Table 3: Correlation matrix

\begin{tabular}{|c|c|c|c|c|c|c|c|c|c|c|}
\hline & ARP & IHP & APP & $\mathrm{CCC}$ & CATAR & CLTAR & CR & DR & FS & SG \\
\hline ARP & 1.0000 & & & & & & & & & \\
\hline IHP & 0.0661 & 1.0000 & & & & & & & & \\
\hline APP & 0.4088 & 0.1215 & 1.0000 & & & & & & & \\
\hline $\mathrm{CCC}$ & 0.3725 & 0.8093 & -0.1101 & 1.0000 & & & & & & \\
\hline CATAR & 0.0473 & 0.1292 & 0.0803 & 0.1034 & 1.0000 & & & & & \\
\hline CLTAR & 0.0071 & -0.2059 & 0.2438 & -0.2858 & 0.2314 & 1.0000 & & & & \\
\hline CR & -0.0554 & 0.1527 & -0.1746 & 0.1827 & 0.1580 & -0.4399 & 1.0000 & & & \\
\hline DR & -0.0444 & -0.1805 & 0.1174 & -0.2351 & 0.0124 & 0.5540 & -0.1960 & 1.0000 & & \\
\hline FS & -0.1361 & -0.1934 & -0.0629 & -0.2133 & 0.1289 & 0.3040 & -0.1433 & 0.0250 & 1.0000 & \\
\hline SG & -0.0699 & -0.1333 & 0.0219 & -0.1587 & 0.0873 & 0.1097 & -0.0675 & 0.0327 & 0.1101 & 1.0000 \\
\hline
\end{tabular}

Source: STATA out put of Data

Table 3 shows that the absence of severe multicollinearity problem in the model since the correlation matrix among explanatory variables is less than 0.9 .

\subsubsection{Hausman test.}

In order to decide fixed or random model, the study used Hausman test. The null hypothesis of the Hausman test was Random effect model is appropriate.

Table 4: Hausman test

\begin{tabular}{|c|c|}
\hline hi2(10) & $(b-B) '\left[\left(V_{-} b-V_{-} B\right)^{\wedge}(-1)\right](b-B)$ \\
& $=\quad 11.78$ \\
& Prob $>$ chi2 $=0.3000$
\end{tabular}


Table 4 Hausmen specification test shows a chi-square of 11.78 with a P-value of 0.3000 . Hence, the null hypothesis of the model which is random effect model is appropriate failed to reject $5 \%$. Moreover, Breusch and pagan Lagrangian Multiplier (LM) test were used to decide random effects or pooled OLS. The null hypothesis of the test was that the Pooled OLS is appropriate.

Table 5: Breusch and pagan Lagrangian Multiplier (LM) test

\begin{tabular}{|c|c|}
\hline I $\quad$ Var $\quad$ sd $=$ & $=\operatorname{sqrt}($ Var $)$ \\
\hline .0326804 & 1807772 \\
\hline e | .0101159 & .1005779 \\
\hline .0087814 & .0937093 \\
\hline
\end{tabular}

Test: $\operatorname{Var}(\mathbf{u})=0$

chibar2(01) $=103.72$

Prob $>$ chibar2 $=0.0000$

Table 5, LM test shows a chibar2 (01) of 103.72 with a P-value of 0.0000 hence the null hypothesis of the model which is pooled OLS model is appropriate is rejected at 1\%. Therefore, Random effect model is appropriate for the study.

\subsection{Result and Discussions}

Table 7: Regression result of the model

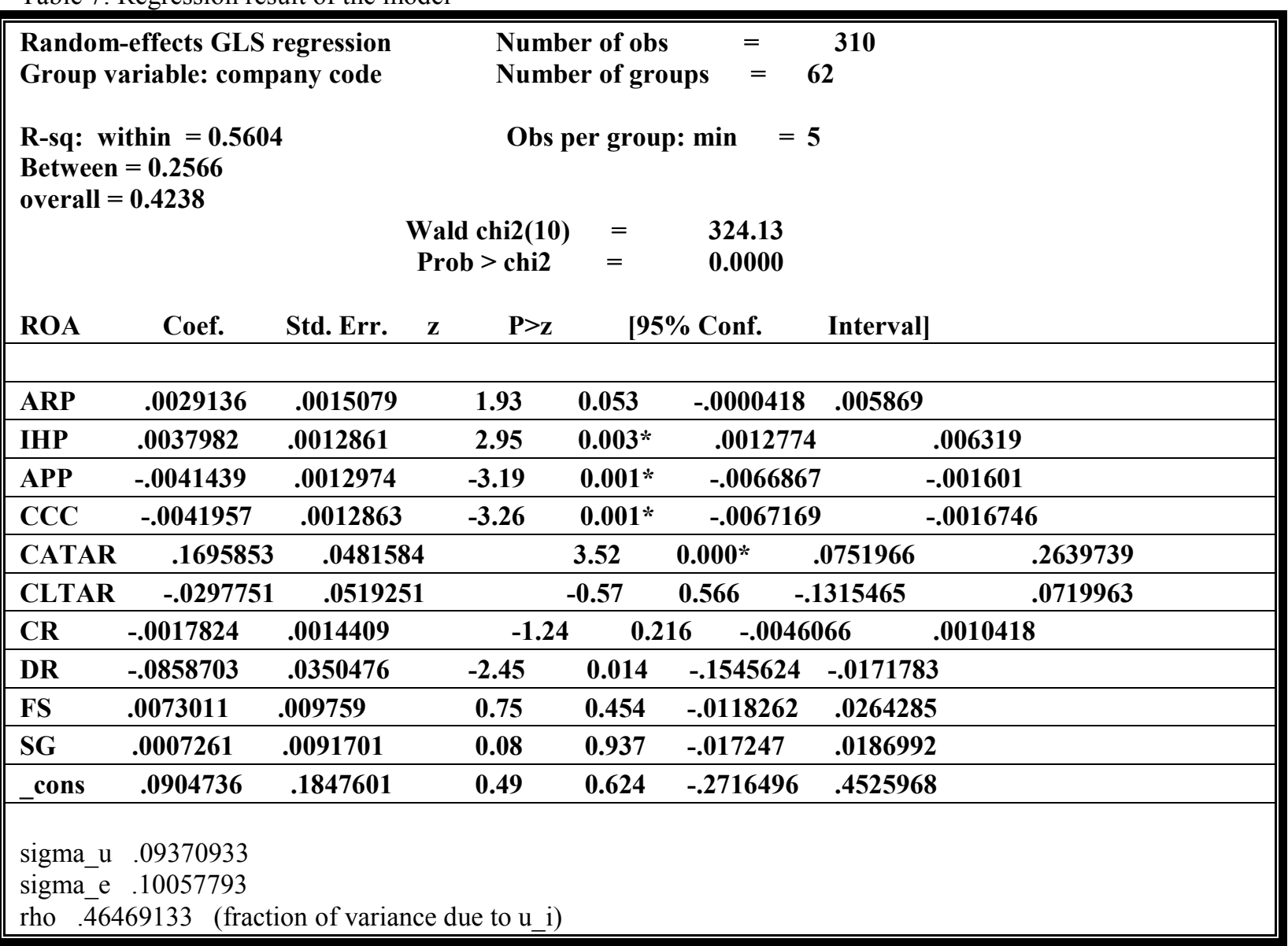

Significant at $1 \% *$

Source: STATA out put of Data

The result of regression table 7 shows, the model adjusted $\mathrm{R}^{2}$ is $56.1 \%$. This implies that $56.1 \%$ of the variations in the profitability of the firms are explained by the independent variables of the model. In other words $56.1 \%$ variation of profitability of sample wholesale firm's explained by independent variable while the remaining $43.9 \%$ of variation of profitability will be explained by other factors which are not included in the model. There is a rule of thumb when the value of $\mathrm{R}^{2}$ greater than $50 \%$, the model was moderately fit. In addition, the value of wald $\mathrm{chi}^{2}$-test which used to explains the overall fitness of a model, has a value of 324 with p-value of 0.000 which 
is highly significant at $1 \%$.

\subsubsection{Relationship Between Accounts Receivable Period and Profitability}

The result of regression shows that ARP was positively related with profitability however it is not statistically significant at $5 \%$. The result implied that, when ARP increased bay a day on average profitability also increase by $0.29 \%$ but not significant. The reason is that aggressively collecting receivable adversely affects wholesale firms profitability. The result is in line with findings of Chebet (2014), and Mbawni et al. (2016) who found positive but non-significant relation between average days of receivable and profitability. However, this result contradicts with the finding of most studies e,g, Lazaridis \&Tryfonidis (2006), Raheman and Nasr (2007), Akoto et al. (2013), Sathyamoorthi et al.(2018). Thus, H1 significant negative relation between ARP and profitability is rejected.

\subsubsection{Relationship Between Inventory Holding Period and Profitability}

The result of regression shows that IHP was positively related with profitability and it is statistically significant at $1 \%$ meaning that, a day increase in inventory holding period results an increase in profitability by $0.37 \%$. Firm can increase their profitability by increasing the period of inventory hold by a firm. The reason is because of holding higher amount of inventory in store reduces the risk of a stock-out during selling process. Keeping optimal amount of inventories also helps in reducing the cost of supplying goods and protects the firm against price fluctuations because of adverse macroeconomic factors. Wholesalers are participating in import and export trade which is vulnerable to price fluctuations. In general, the finding suggests that, the more inventory wait results bettor profitability. This finding consistent with Matheva (2010) who found a significant positive relationship between inventory conversion period and profitability. The result also supported by Makori \& Jagongo (2013), Şamiloğlu \& Akgün (2016), Gambo \& Abdulkarimibn (2016), Kasozi(2017). However, the result obtained is inconsistent with most prior studies Deloof (2003), Lazaridis \& Tryfonidis (2006), Yadav \& Kumar (2014), Arega et al. (2016). Thus, H2 significant negative relation between IHP and profitability is rejected.

\subsubsection{Relationship Between Accounts Payable Period and Profitability}

The result of regression shows that APP was negatively related with ROA and significant at $1 \%$. This means that, a period increase in account payable period by one day results a reduction in profitability by $0.41 \%$. Wholesalers purchase products from manufacture in delay payments and when the period of payable longer, may results lower profitability because of interest rate fluctuations and not using cash discount for early payment. In general the finding confirmed that, less profitable firms wait longer periods to pay their obligation. This finding is consistent with Arega et al. (2016) who explained that the longer a firm wait to pay its obligation leads to lower profitability when there is a benefit of discount for early payment. This finding also supported by Lazaridis \&Tryfonidis (2006), Deloof (2003), Raheman \& Nasr (2007), Sharma \& Kumar (2011), Şamiloğlu \& Akgün (2016). On the contrary of this finding Mathuva (2010), Makori \&Jagongo (2013), and Sathyamoorthi(2018) in their respective shows significant positive relation between APP and profitability. Therefore, H3 significant positive relation between APP and ROA is rejected.

\subsubsection{Relationship Between Cash Conversion Cycle and Profitability}

The regression result revealed that, significant negative relation between CCC of sample wholesale firms with ROA meaning that here is a decrease in ROA by $0.41 \%$ as long as the CCC lengthening by a day. The result support working capital theory which says that cash conversion is significantly negatively related with profitability. The negative relationship suggests that firms can improve their profitability by shortening the time difference between a firm's actual cash in follows and outflows. In other words by decreasing the time interval between expenditure for purchases of products and the collection of cash from sales of products. A shorter cash conversion cycle may improve profitability because it reduces the dependence of firm on external finance for satisfying working capital needs. The shorter CCC is an indication of firm's efficiency in utilizing its working capital. In general the finding suggests that, the shorter CCC results bettor profitability. This finding confirmed by Mathuva (2010) and Makori \&Jagongo (2013) who explained that firms should minimize the period of cash conversion cycle as on as possible in order to improve their profitability. The result consistent to most prior studies like Deloof (2003), Shin \& Soenen (1998), Lazaridis \&Tryfonidis (2006), Arega et al. (2016), Jeyan (2016) ,Şamiloğlu \& Akgün (2016), Ahmed et al. (2016) and contradict with Gill et al. (2010), Uremadu \& Egbide (2012), Sadiq (2016), Sathyamoorthi(2018). Thus, H4 significant negative relation between cash CCC and ROA is confirmed.

\subsubsection{Relationship Between Current Asset to Total Asset Ratio and Profitability}

The regression result indicate that, significant positive relation between CATAR of sample wholesalers and their profitability which means that, there is an increase in profitability by $16.95 \%$ when CATAR increase by one unit. This indicates that, a negative relation between degree of aggressiveness of investment working capital policy and ROA. The higher CATAR indicate the lower the degree of the aggressiveness of working capital investment policy and the higher profitability will be. This finding consists with the fact that mostly wholesalers invest more of it funds on current asset and less of its funds invested in fixed asset. This finding confirmed by Afza \&Nazir (2007) who conclude that firm gets negative returns if they follow an aggressive corking capital investment policy. The result is consistent with Arushad \& Gondal (2013), Mwangi et al. (2014), Jeyan (2016) but, contradict with 
Onwumere (2012), Javid \& Marie Zita (2014), Wahab (2015). Thus, H5 significant negative relation between CATAR and profitably is not supported.

\subsubsection{Relationship Between Current Liability to Total Asset and Profitability}

The regression result revealed that, there was negative relation between CLTAR of sampled wholesale trade firms and their profitability which indicate that, there is a decrease in ROA by $2.97 \%$ when CLTAR increase by one unit, but not significant. This result confirmed by Nirish (2012), Mwangiet al. (2014), Wahab (2015) who found current liability to total ratio has a negative and non-significant impact on profitability. Therefore, H6 significant positive relation between CLTAR and ROA is rejected.

\subsubsection{Relationship Between Control Variables and Profitability}

As we seen in the regression result table 7, there was negative relation between current ratio and return on asset but it is insignificant. The result in line with a theory trade of created between liquidity and profitability objective. There was significant negative relation between debt ratio and firms profitability while Sales growth and firm size had an insignificant positive relationship with profitability.

\section{CONCLUSION AND RECOMMENDATION}

\subsection{Conclusion}

The study empirically examined the impact of working capital management on firm's profitability in case of 62 large tax payers' wholesaler firms for a period of 5 years. The results from random effect regression model are; ARP has insignificant positive relation with ROA. CATAR and IHP has a significant positive relation with ROA. APP and CCC have significant negative relationship with ROA. CLTAR has negative relation with profitability but insignificant.

In line with pervious most empirical studies, the finding of the study confirmed that working capital management significantly affect profitability of wholesale firm. Efficient and effective utilization of resources leads towards profitability. Effective managing of working capital means managing of current asset and current liability on the way profitability would be better. The result of the study suggest that, management of the wholesalers can enhance their company profitably by carefully managing key working capital management variables which strongly affect profitability particularly, management should give more attention to IHP,APP,CCC and CATAR.

\subsection{Recommendation}

Furthermore, the study provides the following recommendations to management of wholesale firms in Addis Abeba.

a. Wholesale firm that stock-up and maintain adequate inventory levels that could decrease the shortage of inventory which leads to higher sales and profitability of a firm. The study recommends that firm should increase the level of inventory to reasonable level in order to improve profitability of a firm and to protect the problem of unexpected price fluctuation of inventory.

b. Wholesale firms should maintain deferral of creditors at minimum possible level to maximize profitability of firm. This could be done by paying its obligation to supplier with earlier time in order to get substantial discounts for early payment and decreasing interest expense.

c. Since strong negative relationship between Cash conversation cycle and return on asset, management should adapt ways of reducing cash conversation cycle in order to enhance profitability of the firms. This could be done by shortening the length of time between cash out flows due to purchase of goods and cash inflows as result of sales of goods to possible optimal minimum level.

d. Lastly, strong positive relationship between current asset to total asset ratio and return on asset, management should implement ways of increasing working capital in order to improve their profitability. This could be done by investing more of its funds on current asset than fixed asset (follows conservative working capital investment policy).

\section{REFERENCES}

Afza, T ,. (2007). Is it better to be aggressive or conservative in managing working capital? journal of quality and technology management, 3(2), 11-21.

Ahmed, Z., Awan, Z., Safdar, Z., \& Hasnain, T. (2016). A nexus between working capital management and profitability: a case study of pharmaceutical sector in pakistan. international journal of economics and financial issues, vol 6, pp 153-159.

Akoto, k., Vitor, A., \& Angmor, L. (2013). Working capital management and profitability:Evidence from Ghanaian listed manufacturing firms. Journal of Economics and International Finance, Vol. 5(9), pp. 373379

Ali, A., \& Ali, A. (2012). Working capital management: is it really affects the profitability ? evidence from pakistan. global journal of management and business research, volume 12 issue 17 version 1.0 year 2012, pp 
75-78.

Amitdas, A. B. (2015). Underlying relationship between working capital management and profitability of pharmaceutical companies. american journal of theoretical and applied business, vol. 1, no. 1, 2015, pp. 2736.

Arega, S., Tadele, T., \& Tadesse, K. (2016). Working capital management and its impact on profitability evidence from food complex manufacturing firms in addis ababa. international journal of scientific and research publications, volume 6 , issue 6 , pp 815-833.

Arshad, Z., \& Gondal, Y. (2013). Impact of working capital management on profitability a case of the pakistan cement industry. Vol 5, no 2 june 2013, PP 384-390.

Bjorkman, H., \& Hillergren, M. (2014). The effects of working capital management on firm profitability. umea school of business and economics.

Brigham, f., \& Houston, F. (2003). Fundamentals of financial management (10 th ed.). New York: McGraw-Hill Inc.

Brooks, C. (2008). Introductory econometrics for finance. (2 ED, Ed.) Cambridge university, Newyork.

Charitou, S., Elfani, M., \& Lois, P. (2010). The effect of working capital management on firm's profitability: empirical evidence from an emerging market. journal of business $\&$ economics research, volume 8 , number 12 , pp 63-68.

Chebet, R. (2014). The effect of working capital management practices on the financial performance of manufacturing firms in nairobi county.

Deloof, M. (2003). Does working capital management affect profitability of Belgian firms. Journal of Business Financeand Accounting, Vol 30, No. 3 \&4, 573-588.

Deresse, M., \& Abiy, G. (2014). Working capital management practices: a study on business enterprises in jimma town, ethiopia. Volume no.2, issue no.6, pp 55-66.

Egbide, B. (2009). Working capital management and profitability of listed companies in Nigeria. Nigeria Research Journal of Accountancy, 1(1), PP 44-57.

Eljelly, A. (2004). Liquidity-profitability tradeoff: an empirical investigation in an emerging market. International Journal of Commerce and Management, PP 48-61.

ERCA. (2015). Ethiopian revenue and customs authority, List of whole sale trade large tax payers in Ethiopia.

Gambo, J., \& Abdulkarim ibn, S. (2016). Empirical examination of the association of working capital management and firms' profitability of the listed food and beverages firms in nigeria. International Refereed Research Journal, Vol.- VII, Issue - 1, PP 12-21.

Gill, A., Biger, N., \& Mathur, N. (2010). The relationship between working capital management and profitability:evidence from the united states. business and economics journal, volume 2010: bej-10, pp 1-9.

Gujarati, D. (2004). Basic econometrics (4 th ed .). McGraw-Hill Companies.

Hair, J. F. (2006). Multivariate data analysis. New York: Prentice Hal.

Hassan, J., \& Ali, I. (2016). Effects of working capital management on firm profitability in merchandise companies in mogadishu, somalia. ijrdo - journal of business management, volume-2, pp 290-299.

Javid, S., \& Marie zita, P. (2014). Impact of working capital policy on firm's profitability a case of pakistan cement industry. research journal of finance and accounting, vol.5, no.5, 2014, pp 183-191.

Jeyan, S. (2016). Working capital management and firms "e profitability: the listed companies in sri lankan context. suganya international journal of emerging research in management \&technology, volume-5, issue-7, pp 6-11.

Lazaridis, I., \& Tryfonidis, D. (2006). The relationship between working capital management and profitability of listed companies in the Athens Stock Exchange. Journal of FinancialManagement and Analysis, Vol 19(1).

Louw, E.(2014) impact of working capital managment on profitablity of south african retail companies. universtiy of pretoria.

Machiraju, H. R. (1999). Introduction to Project Finance and an Analytical Perspective. Vikas Horn.V.J.C.

Makori, M., \& Jagongo, A. (2013). Working Capital Management and Firm Profitability: Empirical Evidence from Manufacturing and Construction Firms Listed on Nairobi Securities Exchange, Kenya. International Journal of Accounting and Taxation, Vol. 1 No. 1, PP 1-14.

Mathuva, d. (2010). the influence of working capital management components on corporateProfitability: a survey on Kenyan listed firms. Research Journal of Business Management, 3:1-11.

Mbawuni, j., Mercy Hawa, M., \& Gyasi, N. (2016). The impact of working capital capital management on profitability of petroleum retail firms. international journal of economics and finance, vol. 8, no. 6; 2016.

Mwangi, W., Makau, S., \& Kosimbei, G. (2014). Effects of working capital management on performance of nonfinancial companies listed in nse, kenya. european journal of business and management, vol.6, no.11, 2014, pp195-205.

Nair, K. (2011). Working capital management. School of distance education.

Niresh, A. (2012). Working capital management \& financial performance ofmanufacturing sector in sri lanka. european journal of business and management, vol 4, no.15, 2012, pp 23-30. 
Onwumere, J., Ibe, G., \& Ugbam, C. (2012). The Impact of Working Capital Management on Profitability of Nigerian Firms: A Preliminary Investigation. European Journal of Business and Management, Vol 4, No.15, 2012, pp $192-201$

Pallant, J. (2005). SPSS survival manual: a step by- step guide to data analysis using SPSS for. Buckingham: Open University Press.

Pandey, I. (1993). Financial Management (9 th ed.). New Delhi: Vikas Publishing House pvt ltd.

Paramasivan, C., \& Subramanian, T. (2009). Financial management. New Delhi-10002: Published by New Age.

Raheman, A., \& Nasr, M. (2007). Working Capital Management And Profitability - Case Of Pakistani Firms. International Review of Business Research Papers, Vol.3 No.1. March 2007, PP 279 - 300.

Ross, S. A., Westerfi eld, R. W., \& Jaffe, J. (2008). Fundamentals of Corporate Finance (4 th ed.). New York: The McGraw-Hill.

Sadiq, R. (2016). Impact of Working Capital Management on Small and Medium Enterprises' Performance in Nigeria. The International Journal Of Business \& Management, Vol 4 Issue 5 , pp 28-35.

Şamilolu, F., \& Akgun, A . (2016). The Relationship between Working Capital Management and Profitability Evidence from Turkey. Business and Economics Research Journal, Volume 7 Number 2, pp 1-14.

Shin, H., \& Soenen, L. (1998). Efficiency of working capital management and corporate profitability. Financial Practice and Education, PP 37-45.

Smith, K.V. (1973). State of the art of Working Capital Management” Financial Managemen. pp. 50-55.

Uremadu, S., \& BC, E. (2012). Working Capital Management, Liquidity and Corporate Profitability among quoted Firms in Nigeria Evidence from the Productive Sector. International Journal of Academic Research in Accounting \& Finance and Management Sciences, 2(1), PP 80-97.

Wahab, A ., Supinah, R., \& Japang, M. (2015). Working Capital Management and Performance of Sabah's Public Listed Firms. International Journal of Managerial Studies and Research, Volume 3, Issue 12, December 2015 , PP 1-6, PP1-6.

Watson, D., \& Head, A. (2007). Corporate Finance Principles \& Practice (4 TH ed.). Pearson Education Limited 2007.

Yadav, K. (2014). Impact of profitability on the determinants of working capital: an evident study of large steel manufacturing companies in India. pp 34-46. BIBLIOGRAPHY \l1033

Kasoz, J. (2017). The Effect of Working Capital Management on Profitability: A Case Of Listed Manufacturing Firms in South Africa. Investment Management and Financial Innovations, Volume 14, Issue 2, 2017, PP 337-346.

Leeshan, S., MUN HAR, W., ONN YOW, T., \& CHUAN SIM, L. (2016). Does Working Capital Management Influence thePerformance of Wholesale and Property Industry inMalaysia? International Journal of Economics and Management Systems, Volume 1, 201, PP 1-4.

Sathyamoorthi, C., Mapharing, M., \& Selinkie, P. (2018). The Impact of Working Capital Management on Profitability:Evidence from the Listed Retail Stores in Botswana. Applied Finance and Accounting, Vol. 4, No. 1, February 2018, pp 82-94.

Padachi, K. (2006). Trends in Working Capital Management and its Impact on Firms'Performance: An Analysis of Mauritian Small Manufacturing Firms. International Review of Business Research Papers, Vo.2 No. 2. October 2006, $45-58$. 